\title{
Distribution patterns of marine bird digenean larvae in periwinkles along the southern coast of the Barents Sea
}

\author{
Kirill V. Galaktionov ${ }^{1}$, Jan Ove Bustnes ${ }^{2, *}$ \\ 'Zoological Institute of the Russian Academy of Sciences, White Sea Biological Station, Universitetskaja nab., 1, \\ St Petersburg, 199034, Russia \\ ${ }^{2}$ Norwegian Institute for Nature Research, Department of Arctic Ecology, The Polar Environmental Centre, 9296 Tromsø, \\ Norway
}

\begin{abstract}
An important component of the parasite fauna of seabirds in arctic regions are the flukes (Digena). Different species of digeneans have life cycles which may consist of 1 intermediate host and no free-living larval stages, 2 intermediate hosts and 1 free-living stage, or 2 intermediate hosts and 2 free-living larval stages. This study examined the distribution of such parasites in the intertidal zones of the southern coast of the Barents Sea (northwestern Russia and northern Norway) by investigating 2 species of periwinkles (Littorina saxatilis and L. obtusata) which are intermediate hosts of many species of digeneans. A total of 26020 snails from 134 sampling stations were collected. The study area was divided into 5 regions, and the number of species, frequency of occurrence and prevalence of different digenean species and groups of species (depending on life cycle complexity) were compared among these regions, statistically controlling for environmental exposure. We found 14 species of digeneans of which 13 have marine birds as final hosts. The number of species per sampling station increased westwards, and was higher on the Norwegian coast than on the Russian coast. The frequency of occurrence of digeneans with more than 1 intermediate host increased westwards, making up a larger proportion of the digeneans among infected snails. This was significant in $L$. saxatilis. The prevalence of different species showed the same pattern, and significantly more snails of both species were infected with digeneans with complicated life cycles in the western regions. In L. saxatilis, environmental exposure had a statistically significant effect on the distribution of the most common digenean species. This was less obvious in L. obtusata. The causes of changing species composition between regions are probably (1) the harsh climate in the eastern part of the study area reducing the probability of successful transmission of digeneans with complicated life cycles, and (2) the distribution of different final hosts.
\end{abstract}

KEY WORDS: Seabirds · Parasites - Trematoda - Digenea - Barents Sea - Distribution

\section{INTRODUCTION}

The distributions of seabird parasites are not well known in arctic regions. In the Barents Sea area (northwestern Russia and northern Norway) there have been no studies of the broad-scale geographical variation in the distribution of such organisms, but small-scale studies have shown that flukes (Digenea)

\footnotetext{
-Addressee for correspondence.

E-mail: jan.o.bustnes@ninatos.ninaniku.no
}

constitute an important part of the seabird parasite fauna in the area (Belpolskaya 1952, Galaktionov 1995, 1996).

Most seabird digeneans have complicated life cycles with 1 or more intermediate hosts. This should be taken into account in analyses of the geographical distribution of helminths (Hoberg 1996, 1997). A record of adult digeneans in individual seabirds does not necessarily mean that completion of the life cycle of the species is possible at the location where the bird was captured, since the bird may have become infected in a different area. More reliable information about the dis- 
tribution of the digenean fauna may be gained from examining the larval composition of the intermediate hosts, particularly the first host, which are intertidal and upper-subtidal gastropod molluscs such as periwinkles Littorina spp. These molluscs are distributed widely along the intertidal zone of northern seas and play an important role as the first intermediate host for many common seabird digeneans (Chubrick 1966, James 1968, 1969, Werding 1969, Podlipajev 1979, Lauckner 1980, 1984a, 1987, Irwin 1983, Matthews et al. 1985, Galaktionov \& Dobrovolskij 1986, Kristoffersen 1991, Galaktionov 1993).

The most typical life cycles of digeneans involve 2 intermediate hosts. There may be 1 (cercaria) or 2 (miracidia and cercaria) free-living stages in such life cycles. A genus with 2 free-living stages commonly found in the Barents Sea is Himasthla, while digeneans with 1 free-living larval stage are Microphallus similis, Cryptocotyle lingua, and the genus Renicola. The second intermediate host may be omitted from the life cycle; the cercaria then encysts in the environment (e.g. the genus Notocotylus). In some cases the metacercariae mature inside sporocysts in the molluscan host that combine, to some extent, the function of both the first and the second intermediate hosts. Some of these life cycles are devoid of free-swimming larval stages (miracidia and cercaria) (Galaktionov 1993, 1996). A common group of digeneans with such life cycles are the microphallids of the 'pygmaeus' group (Microphallus pygmaeus, $M$. piriformes, etc.), which are common in the Barents Sea region (Chubrick 1966 . Podlipajev 1979, Galaktionov \& Dobrovolskij 1986, Galaktionov 1993).

Our aim was to examine the distribution of seabird digeneans with different life cycle complexity in 2 species of periwinkles (Littorina saxatilis and $L$. obtusata), along a climatic gradient on the southern coast of the Barents Sea. The area stretched from the arctic Novaya Zemlya in the east to the milder coastal area around Tromse in the west (Fig. 1). We divided the area into 5 naturally separated regions (Fig. 1) and compared the frequency of occurrence and prevalence of digenean species with varying life cycle complexity among the different regions, controlling statistically for environmental exposure.

\section{MATERIALS AND METHODS}

The coastline investigated stretched from Novaya Zemlya to Tromsø, and included the White Sea (Fig. 1). This coast has a very harsh climate, especially in the arctic eastern parts (e.g. Loeng 1991, Åndalsvik \& Loeng 1991). We divided the coastline into 5 different regions, which could be naturally distinguished. Region A was Novaya Zemlya and Vaygatch Island. Region B was the White Sea and the tip of the Kanin peninsula. Region $C$ was the eastern Kola coast to the Kola fjord (eastern Murman). Region D was the
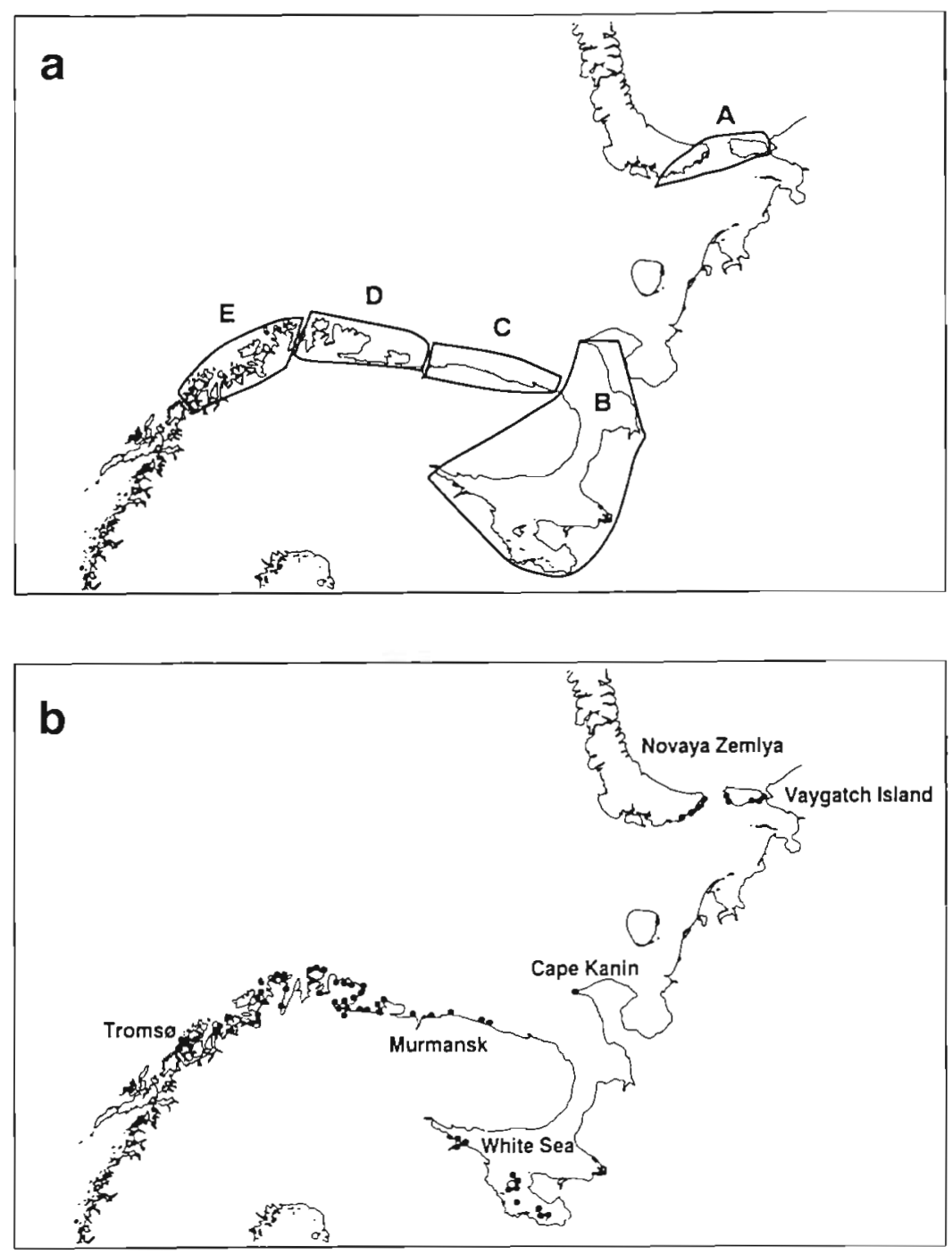

Fig. 1. (a) Division of the study area into different regions (A to E) (see 'Materials and methods'), and (b) the distribution of sampling stations along the southern Barents Sea Coast 
western Murman and Finnmark County east of the Porsanger fjord. Region E was western Finnmark and Troms Counties (Fig. 1).

The areas surrounding Novaya Zemlya and Vaygatch have an arctic climate with very low temperatures during the whole year. Sea ice dominates from October to June, and intertidal zones are covered by ice (Loeng \& Vinje 1979, Vinje \& Kvambekk 1991). The climate in the White Sea is milder, but the sea is frozen in winter (December to May) since the water in this region has a low salinity (Lønne et al. 1997). The eastern Kola coast is usually not frozen in winter. There are no large fjords in this region, and the intertidal zones are thus more exposed to wave action (e.g. Åndalsvik \& Loeng 1991). The western Murman and eastern Finnmark have more fjords and the climate is milder, influenced by the North Atlantic and coastal currents. Nevertheless the prevalent wind directions are more easterly than they are further west. Troms and western Finnmark are dominated by westerly winds, and are relatively mild compared to the other regions (Loeng 1991, Loeng et al. 1992, Lønne et al. 1997).

The collection of the material was carried out from 1978 to 1990 in Russia, and in 1992 and 1994 in Norway. We collected totally 26020 snails of 2 species (Littorina saxatilis and L. obtusata) from 134 locations (Table 1). The sampling stations were evenly distributed along the coast in Norway (Fig. 1). In Russia, the stations chosen were more clustered (Fig. 1) because they were remote and access was much more difficult. The sampling locations were roughly predetermined on a map, while the sampling sites were selected as randomly as possible within the predetermined area. All sampling stations were at natural locations (at least $3 \mathrm{~km}$ away from fishing ports and other anthropogenic installations) (see also Bustnes \& Galaktionov 1999).

Of the gastropod species collected, Littorina saxatilis was the most common and widely distributed in the study area, being present even in the arctic littoral zone of Novaya Zemlya and Vaygatch Island (region A). Its northern distribution limit is the southern part of Novaya Zemlya (Karmakulskaja Bay) (Golikov 1995, K. Galaktionov pers. obs.). L. saxatilis inhabits all types of intertidal zones except sand beaches. It is therefore mostly absent in the intertidal zone of the Pechora Sea (southeastern part of the Barents Sea) from the strait of Yugorsky Shar in the east to the tip of the Kanin penisula in the west (Fig. 1). In the rest of the southern Barents Sea, L. saxatilis occurs throughout the intertidal zone, but greatest densities are found in the upper-mid intertidal zone (Golikov 1995). In regions B, C, D and E, L. obtusata is common in the middle and lower levels of the seaweed fronds (Golikov 1995).

Molluscs were collected by hand at low tide. The sampling was done in the same manner and at the same time of year (August and September) at all sites. In this season the infestation of intertidal snails by digenean larvae in arctic areas is at its highest (Chubrick 1966, Galaktionov \& Dobrovolskij 1986. Galaktionov 1992). Snails were dissected under a stereomicroscope, and the digenean larvae were identified in vivo. For the analyses we recorded the presence or absence of different digenean species in each mollusc. Double infections made up a very small proportion (usually less than $1 \%$ ) of the infected snails, and were therefore excluded from the analyses.

We distinguished 5 degrees of exposure to wave action on the sea shores: 1 = most sheltered parts of fjords and bays; 5 = open sea shore; while 2 to 4 were ranked between the 2 extremes.

The digenean species were divided into 2 groups: Group I = microphallids of the 'pygmaeus' group, Maritrema murmanica and Parapronocephalum symmetricum, which have life cycles with 1 intermediate host and no free-living larval stages. Group II = other seabird digeneans with more than 1 intermediate host and free-living larval stages: Microphallus similis, Maritrema arenaria, Cryptocotyle lingua, Renicola sp., Himasthla sp., Notocotylus sp. and Parvatrema sp.

In order to determine the importance of different digenean species, or groups of species, in the faunal composition in different regions, we calculated the frequency of occurrence of each digenean species (\% of all infected snails infected with the digenean in question) among the infected snails. We also calculated prevalence as the percentage of periwinkles infected 
by a particular parasite species or group of species. This was done for all regions.

Statistical analyses were carried out using the GENMOD procedure in SAS (SAS 1990, 1993). To test how the numbers of species at different stations were influenced by longitude and exposure, we used Poisson regression. For comparisons of frequency of occurrence and prevalence of different species between regions, we used logistic regression in the GENMOD procedure. The criteria for assessing goodness of fit of the models showed that for most species the Deviance
value/DF was greater that 1 . This indicated some overdispersion in the data and we used quasi-likelihood estimation with a scaled deviance $=1$ (DSCALE option; SAS 1993) and $F$-tests to test the differences between the regions (McCullagh \& Nelder 1989). In all statistical models we included region and environmental exposure and interactions between these 2 variables as covariates. Interactions were removed when not significant. Some digenean species were so rare that statistical analyses could not be carried out, especially those in Littorina obtusata.

Table 2. List of digenean species found along the southern coast of the Barent Sea. The main intermediate hosts are underlined

\begin{tabular}{|c|c|c|c|c|}
\hline Digenean species & First intermediate host & Second intermediate host & Final host & $\begin{array}{l}\text { No. of free-living } \\
\text { stages }\end{array}$ \\
\hline $\begin{array}{l}\text { Microphallus pygmaeus } \\
\text { (Levinsen, 1881) } \\
\text { (fam. Microphallidae) }\end{array}$ & $\begin{array}{l}\text { Littorina saxatilis, } \\
\text { L. obtusata } \\
\text { L. littorea }\end{array}$ & Absent & $\begin{array}{l}\text { Common eider, } \\
\text { other eiders and } \\
\text { seaducks }\end{array}$ & 0 \\
\hline $\begin{array}{l}\text { M. piriformes (Odhner, 1905) } \\
\text { (Galaktionov, 1983) }\end{array}$ & $\frac{\text { L. Saxatilis, }}{\text { L. obtusata }}$ & Absent & $\begin{array}{l}\text { Large gulls, common } \\
\text { gull, eider }\end{array}$ & 0 \\
\hline $\begin{array}{l}\text { Microphallus sp. I } \\
\text { (M.pseudopygmaeus) } \\
\text { (Galaktionov, 1980) }\end{array}$ & $\begin{array}{l}\text { L. saxatilis, L. obtusata, } \\
\text { Onoba aculeus, Marganites } \\
\text { helicinus, M groenlandicus, } \\
\text { Lacuna vincta }\end{array}$ & Absent & $\begin{array}{l}\text { Common eider, pro- } \\
\text { bably some other } \\
\text { sea ducks }\end{array}$ & 0 \\
\hline $\begin{array}{l}\text { M. triangulatus } \\
\text { (Galaktionov, 1984) }\end{array}$ & $\frac{\text { L. saxatilis }}{\text { L. obtusata }}$ & Absent & $\begin{array}{l}\text { Common eider, probab } \\
\text { some other sea ducks }\end{array}$ & bly \\
\hline $\begin{array}{l}M \text {. similis } \\
\text { (Jagerskioeld, 1900) }\end{array}$ & $\begin{array}{l}\text { L. saxatilis, L. obtusata, } \\
\text { L. Littorea }\end{array}$ & $\frac{\text { Carcinus maenas }}{\text { Hyas araneus }}$ & $\begin{array}{l}\text { Gulls (aL species } \\
\text { in the area studied) }\end{array}$ & $\begin{array}{c}1 \\
\text { (cercaria) }\end{array}$ \\
\hline $\begin{array}{l}\text { Maritrema arenaria } \\
\text { (Hadley \& Castle, } 1940 \text { ) }\end{array}$ & L. saxatilis & $\begin{array}{l}\text { Semibalanus } \\
\text { balanoides }\end{array}$ & $\begin{array}{l}\text { Waders (Arenaria } \\
\text { interpres) }\end{array}$ & $\frac{1}{\text { (cercaria) }}$ \\
\hline $\begin{array}{l}\text { M. murmanica } \\
\text { (Galaktionov, 1989) }\end{array}$ & L. saxatilis & Absent & Unknown & 0 \\
\hline $\begin{array}{l}\text { Cryptocoryle lingua } \\
\text { (Creplin, 1825) (fam. } \\
\text { Heterophiidae) }\end{array}$ & $\begin{array}{l}\text { L. Littorea, } \\
\text { L. Saxatilis, } \\
\text { L. obtusata }\end{array}$ & $\begin{array}{l}\text { Seafish, different } \\
\text { species (cod, flatfish, } \\
\text { salmon, etc.) }\end{array}$ & $\begin{array}{l}\text { Gulls (all species in } \\
\text { the area studied) }\end{array}$ & $\begin{array}{c}1 \\
\text { (cercaria) }\end{array}$ \\
\hline $\begin{array}{l}\text { Himasthla sp. (Podlipajev, } \\
\text { 1979) (fam. Echino- } \\
\text { stomatidae) }\end{array}$ & $\begin{array}{l}\text { L. Saxatilis, } \\
\text { L. obtusata, } \\
\text { L. Littorea }\end{array}$ & Mytilus edulis & $\begin{array}{l}\text { Gulls (herring gull, } \\
\text { great black-backed } \\
\text { gull) }\end{array}$ & $\begin{array}{l}2 \\
\text { (miracidium, } \\
\text { cercaria) }\end{array}$ \\
\hline $\begin{array}{l}\text { Renicola sp. (Podlipajev, } \\
\text { 1979) (fam. Renicolidae) }\end{array}$ & $\begin{array}{l}\text { L. saxatilis, } \\
\text { L. obtusata, } \\
\text { L. Iittorea }\end{array}$ & $\frac{\text { Mytilus edulis, }}{\text { Littorina spp. }}$ & Gulls (?) & $\begin{array}{c}1 \\
\text { (cercaria) }\end{array}$ \\
\hline $\begin{array}{l}\text { Parapronocephalum } \\
\text { symmetricum } \\
\text { (Belopolskaya, 1952) } \\
\text { (fam. Pronocephalidae) }\end{array}$ & $\begin{array}{l}\text { L. Saxatilis, } \\
\text { L. obtusata }\end{array}$ & Absent & $\begin{array}{l}\text { Shorebirds (sandpipers } \\
\text { oystercatcher) }\end{array}$ & rs \\
\hline $\begin{array}{l}\text { Notocotylus sp. (Podlipajev, } \\
1979) \text { ( } 2-3 \text { different species) } \\
\text { (fam. Notocotilidae) }\end{array}$ & $\begin{array}{l}\text { L. saxatilis, } \\
\text { L. obtusata, } \\
\text { Skeneopsis planorbis }\end{array}$ & Absent & Seaducks & $\begin{array}{c}1 \\
\text { (cercaria) }\end{array}$ \\
\hline $\begin{array}{l}\text { Parvatrema sp. } \\
\text { (Podlipajev, 1979) } \\
\text { (fam. Gymnophallidae) }\end{array}$ & Unknown & $\begin{array}{l}\text { L. saxatilis } \\
\text { L. obtusata }\end{array}$ & $\begin{array}{l}\text { Common eider, } \\
\text { shorebirds }\end{array}$ & $\begin{array}{c}1 \\
\text { (cercaria) }\end{array}$ \\
\hline $\begin{array}{l}\text { Podocotyle atomon } \\
\text { (Rudolphi, 1802) } \\
\text { (fam. Opecoelidae) }\end{array}$ & $\begin{array}{l}\text { L. Saxatilis, } \\
\text { L. obtusata, } \\
\text { L. Iittorea }\end{array}$ & $\begin{array}{l}\text { Intertidal gammarids } \\
\text { (Gammarus spp., } \\
\text { Marinogammarus } \\
\text { obtusatus) }\end{array}$ & $\begin{array}{l}\text { Marine fishes } \\
\text { (122 species) }\end{array}$ & $\begin{array}{c}2 \\
\text { (miracidium, } \\
\text { cercaria) }\end{array}$ \\
\hline
\end{tabular}




\section{RESULTS}

Sporocysts and rediae as well as cercariae and metacercariae of 14 digenean species were found (Table 2). Thirteen of these have marine birds as final hosts. The exception, Podocotyle atomon, has fishes as a definitive host, and was excluded from all further analyses (Table 2). From the Barents Sea area, distinct species of the genera Renicola, Himasthla, Nocotylus and Paravatrema were described by Podlipajev (1979) based on morphological characteristics. However, Podlipajev (1979) only used genus names because of lack of detailed knowledge about life cycles. More recent studies also identified these species (K. Galaktionov unpubl. data), and in this study we refer to them by the genus name and 'sp.' (Table 2).

The lowest number of digenean species $(n=5)$ in Littorina saxatilis was found in Novaya Zemlya (region A), but the number of digenean species increased to 6 at the tip of the Kanin peninsula, and to 10 on the coasts of Onega and Kandalaksha Bays in the White Sea (region B). On the eastern Murman coast (region C) we found 11 species, and 13 and 12 species in western Murman/eastern Finnmark (region D) and western Finnmark/Troms (region E), respectively. The most diverse digenean fauna in $L$. obtusata was also recorded in the western regions ( $D$ and $E$ ), and the least diverse in the eastern Murman (region C). The differences in diversity between regions were significant for both host species when controlling for exposure (Table 3 ).

\section{Frequency of occurrence of digenean species in different regions}

In all regions, microphallids of the 'pygmaeus' group (Group I) dominated the seabird digeneans in both Littorina saxatilis and L. obtusata (Fig. 2).

At Novaya Zemlya and Vaygatch almost all parasitized snails were infected with Group I (life cycles with 1 intermediate host and no free-living larval stages) digeneans (frequency of occurrence $=99 \%$ of infected snails). In regions $\mathrm{B}$ and $\mathrm{C}$ the frequency of Group I digeneans was ca $90 \%$ in both Littorina sax-

Table 3. Multiple Poisson regression of the effect of region, controlled for environmental exposure, on the number of digenean species in 2 periwinkles at sampling locations along the southern coast of the Barents Sea and the White Sea

\begin{tabular}{|lccccccc|}
\hline Host species & \multicolumn{3}{c}{ Exposure } & & \multicolumn{3}{c|}{ Region } \\
& df & $\chi^{2}$ & $\mathrm{p}$ & $\mathrm{df}$ & $\chi^{2}$ & $\mathrm{p}$ \\
\hline Littorina saxatilis & 4,125 & 5.12 & 0.275 & 4,125 & 73.54 & $<0.0001$ \\
L. obtusata & 4,35 & 11.03 & 0.026 & 3,35 & 12.0 & 0.0074 \\
\hline
\end{tabular}
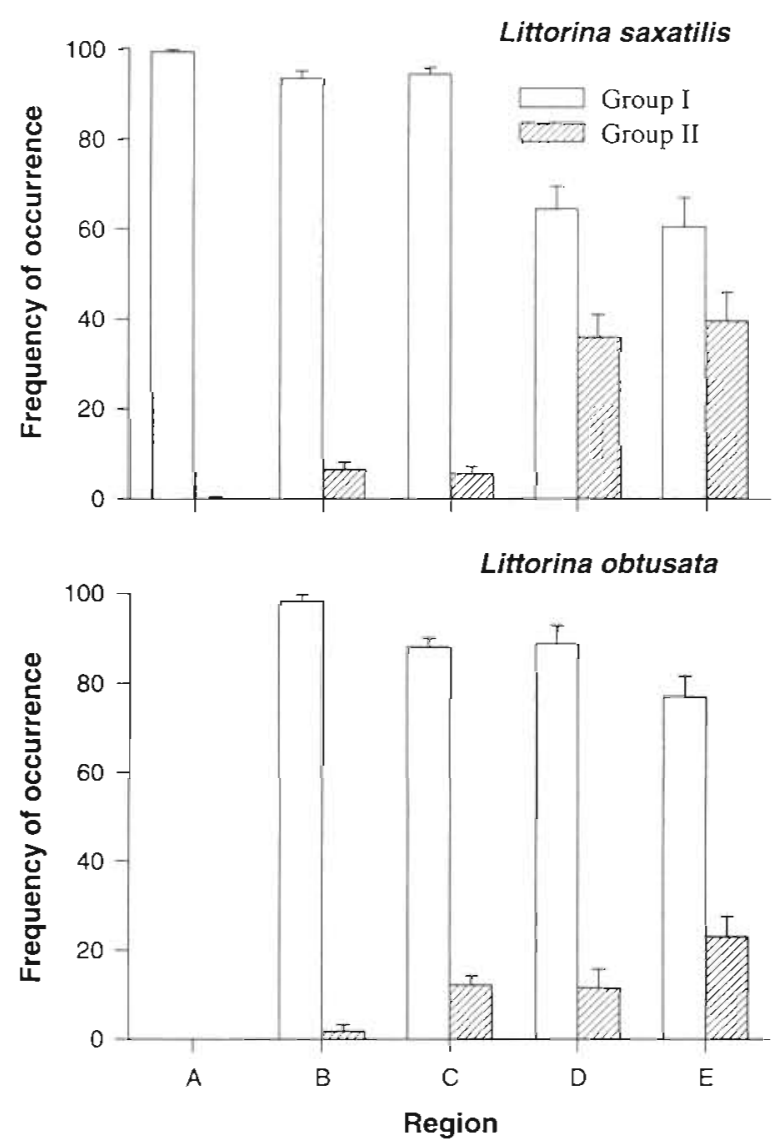

Fig. 2. Frequency of occurrence of 2 groups of digenean species (Group I = species with 1 intermediate host and no free-living larval stages in their life cycles; Group II = species with life cycles including more than 1 intermediate host and free-living larval stages) in 2 species of periwinkles (infected snails only) in different regions of the Barents Sea and the White Sea

atilis and L. obtusata (Fig. 2). In L. saxatilis, the frequency of Group I digeneans decreased to $60 \%$ in the 2 westernmost regions ( $D$ and $E$ ), while Group II digeneans increased correspondingly (Fig. 2). These regional changes were significant $\left(F_{4,116}=28.86, \mathrm{p}<\right.$ $0.0001)$ when controlling for exposure $\left(F_{4,116}=1.94, \mathrm{p}=\right.$ $0.108)$. In L. obtusata Group I digeneans decreased to $77 \%$ in region $E$ (Fig. 2), but this was not significant $\left(F_{4,34}=1.48, \mathrm{p}=0.24\right)$ when controlling for exposure $\left(F_{4,34}=0.85, \mathrm{p}=0.504\right)$.

At the species level, the frequency of occurrence of Microphallus pygmaeus, which was the commonest of the Group I species, decreased significantly westwards in both Littorina saxatilis and L. obtusata (Table 4). The second most important species in Group I, $M$. piniformes, increased in frequency of occurrence westwards and was also very common in $L$. saxatilis in the White 

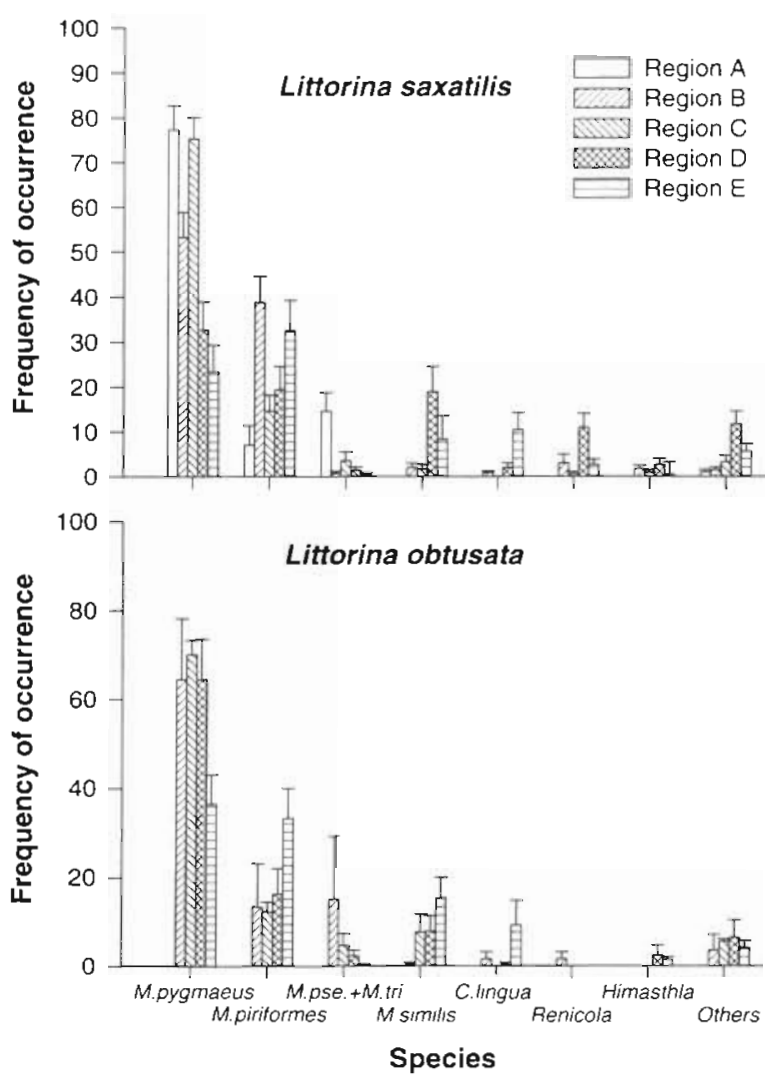

Fig. 3. Frequency of occurrence of different digenean species in 2 species of periwinkles (infected snails only) in different regions of the Barents Sea and the White Sea

Sea (region B) (Fig. 3, Table 4). In region E, this parasite was more common in $L$. saxatilis than $M$. pygmaeus (Fig. 3). In L. obtusata the frequency of $M$. piriformes increased considerably westwards, but the level in the White Sea was low (Fig. 3, Table 4),

Table 4. Multiple logistic regression testing the effects of region, controlled for environmental exposure, on the frequency of occurrence of different digeneans in Littorina saxatilis and L. obtusata along the southern coast of the Barents Sea and the White Sed

\begin{tabular}{|c|c|c|c|c|c|c|}
\hline \multirow{2}{*}{$\begin{array}{l}\text { Host species } \\
\text { Digenean species }\end{array}$} & \multicolumn{3}{|c|}{ Exposure } & \multicolumn{3}{|c|}{ Region } \\
\hline & df & F & $\mathrm{p}$ & $\mathrm{df}$ & F & $\mathrm{p}$ \\
\hline \multicolumn{7}{|l|}{ Littorina saxatilis } \\
\hline Microphallus pygmaeus & 4,112 & 41.43 & $<0.0001$ & 4,112 & 79.55 & $<0.0001$ \\
\hline M. piriformes & 4,112 & 37.87 & $<0.0001$ & 4,112 & 82.38 & $<0.0001$ \\
\hline M. similis & 4,112 & 14.99 & 0.0047 & 4,112 & 76.19 & $<0,0001$ \\
\hline Cryptocotyle lingua & 4,112 & 21.69 & $<0.0001$ & 4,112 & 114.29 & $<0.0001$ \\
\hline Renicolasp. & 4,112 & 6.62 & 0.15 & 4,112 & 76.36 & $<0.0001$ \\
\hline \multicolumn{7}{|l|}{ Littorina obtusata } \\
\hline Microphallus pygmaeus & 4,33 & 5.46 & 0.24 & 3,33 & 11.16 & 0.011 \\
\hline M. piriformes & 4,35 & 5.76 & 0.23 & 3,33 & 9.50 & 0.023 \\
\hline$M$. similis & 4,33 & 5.21 & 0.27 & 3,33 & 3.73 & 0.29 \\
\hline
\end{tabular}
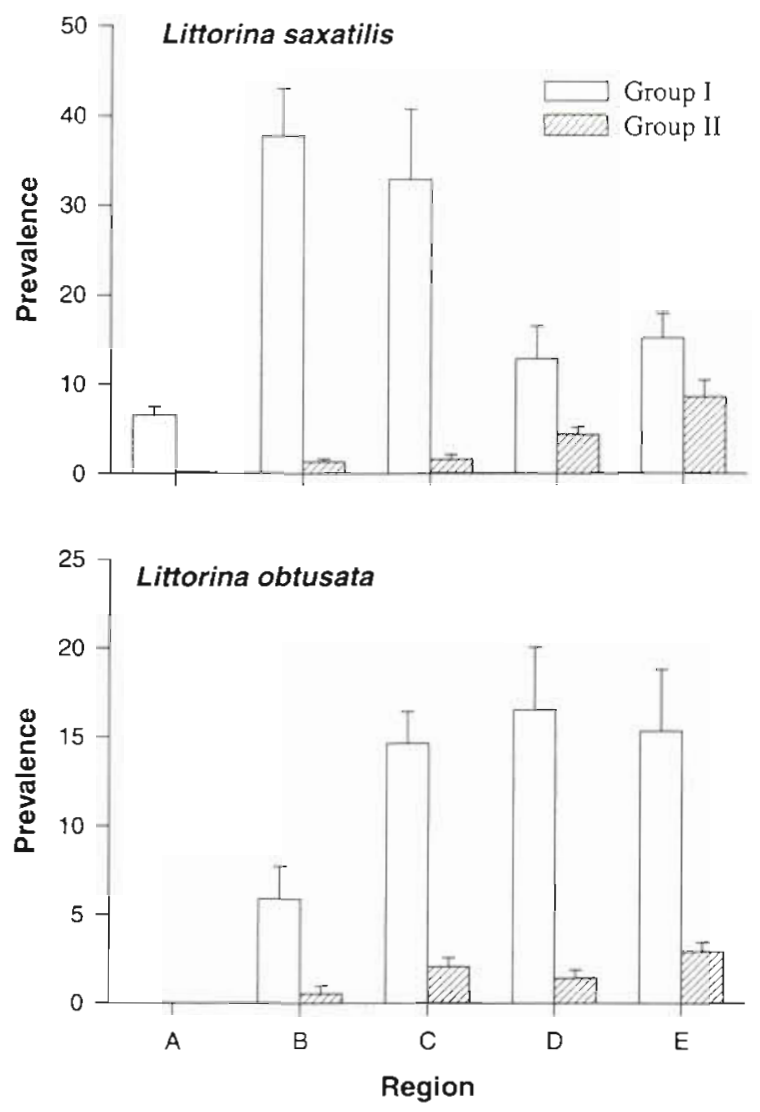

Fig. 4. Prevalence ( $\%$ of snails infected) of 2 groups of digenean species (Group I = species with 1 intermediate host and no free-living larval stages in their life cycles; Group II = species with life cycles including more than 1 intermediate host and free-living larval stages) in 2 species of periwinkles in different regions of the Barents Sea and the White Sea

In Littorina saxatilis, Group II digeneans such as Microphallus similis, Cryptocotyle lingua, Himasthla sp. and Renicola sp. increased significantly westwards (Fig. 3, Table 4). In L. obtusata most Group II parasites were so rare that statistical tests among regions could not be carried out except for $M$. similis, which did not show any significant difference between regions (Fig. 3 , Table 4).

\section{Prevalence of different digenean in different regions}

In Littorina saxatilis the prevalence of digeneans (all species pooled) was lowest $(6.5 \%)$ in region $A$, and highest in regions $B$ $(39 \%)$ and $C(34.5 \%)$. In the 2 
westernmost regions the prevalence was $17.2 \%$ (D) and $23.7 \%$ (E). In L. obtusata prevalence was lowest in region $\mathrm{B}(6 \%)$, intermediate in region $\mathrm{C}(16.7 \%)$ and highest in regions $\mathrm{D}$ and $\mathrm{E}(17.9$ and $18.2 \%$ respectively).

There was a westward decrease in the prevalence of digeneans with 1 intermedate host and no free-living larval stages in the life cycles (Group I) and increase in prevalence of digeneans with complicated life cycles (Group II) (Fig. 4). This trend was significant for all digenean species (those sufficiently common to be analysed individually) and groups of species that infected Littorina saxatilis and $L$. obtusata, respectively, when controlling for exposure (Table 5).

In region $A$, microphallids of the 'pygmaeus' group dominated through the high prevalence of Microphallus pygmaeus (4.6\%). The prevalence of $M$. piriformes was very low in this region $(0.16 \%)$ (Fig. 5). The highest prevalence of $M$. pygmaeus was found in region $\mathrm{C}$ (eastern Murman) in both Littorina saxatilis (23.6\%) and $L$. obtusata $(11 \%)$. In $L$. saxatilis it decreased to $3.7 \%$ and $5.2 \%$ in regions $D$ and $E$, respectively. In contrast, the prevalence of $M$. piriformes increased westwards (Fig. 5). In L. Saxatilis it was highest in region $B$ (White Sea) (15.9\%) (Fig. 5). In L. obtusata, $M$. piriformes was highest in the westernmost regions. The prevalence of $M$. similis, Cryptocotyle lingua, and Himasthla sp. increased significantly westward in $L$. saxatilis. The same was found in L. obtusata for $M$. similis (Fig. 5, Table 5). Exposure had a significant effect on the prevalence of digeneans in L. saxatilis, but not in L. obtusata (Table 5).
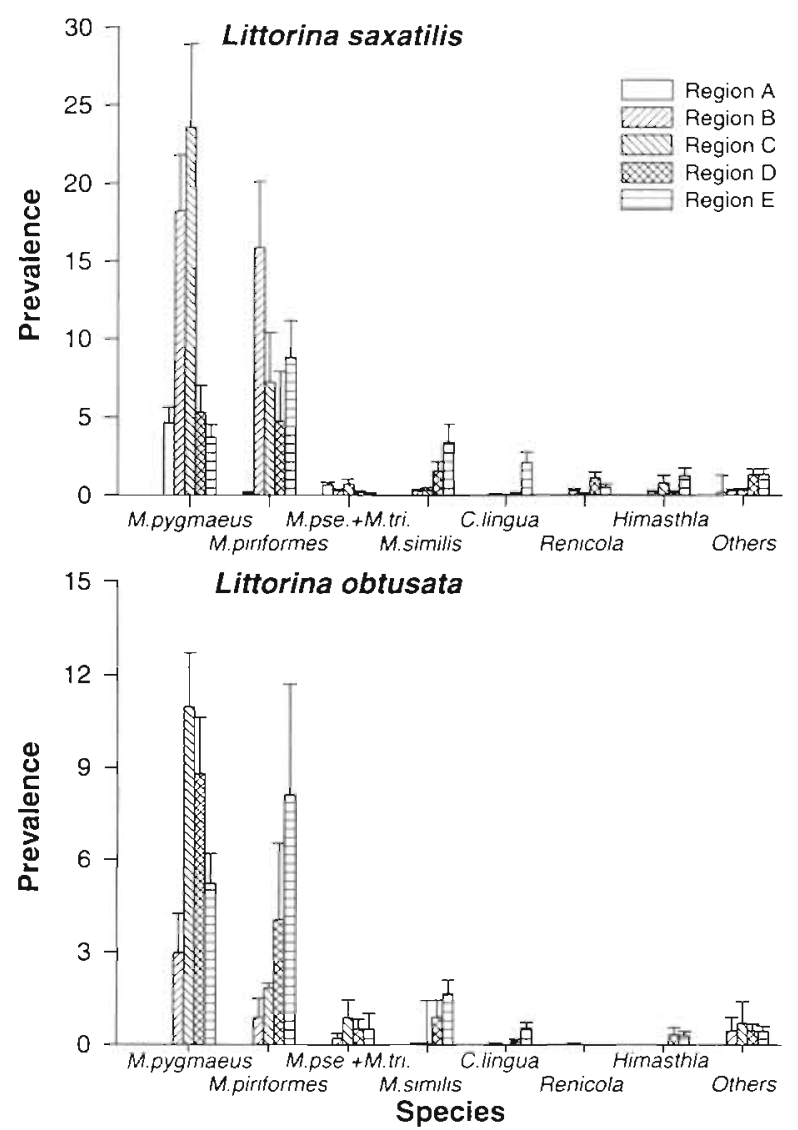

Fig. 5. Prevalence (\% of snails infected) of different digenean species in 2 species of periwinkles in different regions of the Barents Sea
Table 5. Multiple logistic regression testing the effects of region, controlled for environmental exposure, on the prevalence of different digeneans in Littorina saxatilis and L. obtusata along the southern coast of the Barents Sea and the White Sea

\begin{tabular}{|c|c|c|c|c|c|c|}
\hline \multirow{2}{*}{$\begin{array}{l}\text { Host species } \\
\text { Digenean species }\end{array}$} & \multicolumn{3}{|c|}{ Exposure } & \multicolumn{3}{|c|}{ Region } \\
\hline & $\mathrm{df}$ & $F$ & $p$ & $\mathrm{df}$ & $F$ & $\mathrm{p}$ \\
\hline \multicolumn{7}{|l|}{ Littorina saxatilis } \\
\hline Microphallus pygmaeus & 4,125 & 8.23 & 0.083 & 4,125 & 25.02 & $<0.0001$ \\
\hline M. piriformes & 4,125 & 15.35 & 0.004 & 4,125 & 54.31 & $<0.0001$ \\
\hline M. similis & 4,125 & 9.34 & 0.053 & 4.125 & 110.90 & $<0.0001$ \\
\hline Cryptocotyle lingua & 4,125 & 45.81 & $<0.0001$ & 4,125 & 190.92 & $<0.0001$ \\
\hline Himasthla sp. & 4,125 & 17.89 & 0.0013 & 4,125 & 96.04 & $<0.0001$ \\
\hline Group I & 4,123 & 10.65 & 0.031 & 4,123 & 33.56 & $<0.0001$ \\
\hline Group II & 4,125 & 15.06 & 0.0046 & 4,125 & 163.0 & $<0.0001$ \\
\hline \multicolumn{7}{|l|}{ Littorina obtusata } \\
\hline Microphallus pygmaeus & 4,35 & 1.55 & 0.82 & 3,35 & 8.44 & 0.038 \\
\hline M. piriformes & 4,35 & 4.99 & 0.29 & 3,35 & 11.61 & 0.0088 \\
\hline M. similis & 4,35 & 7.02 & 0.14 & 3,35 & 20.69 & $<0.0001$ \\
\hline Group I & 4,35 & 2.91 & 0.57 & 3,35 & 12.41 & 0.0061 \\
\hline Group II & 4,35 & 4.28 & 0.37 & 3,35 & 14.11 & 0.0028 \\
\hline
\end{tabular}

\section{DISCUSSION}

This is the first study to examine the distribution of seabird digeneans on a broad geographical scale in the Barents Sea region. The frequency of occurrence of different digenean species and their prevalence revealed the same pattern. In the eastern regions, the microphallids of the 'pygmaeus' group dominated, whereas in the western regions, the importance of digeneans with complex life cycles increased greatly. This was especially clear in Littorina saxatilis.

The trend in the number of digenean species at each sampling station was also most pronounced in Littorina saxatilis, and was caused by the low number of species in the easternmost region (Novaya Zemlya and Vaygatch). Many of the 
interregional differences in number of species, parasite frequency of occurrence and prevalence can probably be explained by the longitudinal changes in the environmental conditions. In milder climates the 3-host life cycles with 1 free-living larval stage (cercaria) may have a better chance of successful completion than digeneans with no free-living larval stages. This is probably the main reason why digenean species with complex life cycles ( 3 hosts) predominate in the species composition and prevalence in periwinkles on the shores of Germany, France, Britain and Northern Ireland (e.g. James 1969, Werding 1969, Combescot-Lang 1976, Lauckner 1980, 1984b, Hughes \& Answer 1982, Irwin 1983, Matthews et al. 1985, Newell 1986). The cause of this difference is not known, but it is possible that the dispersion of free-swimming cercariae and the metacercariae through the movements of the second intermediate host is more efficient in milder environments. If so, the life cycles without free-living larval stages, such as those of microphallids of the 'pygmaeus' group may only have an advantage over complex life cycles under extreme environmental conditions (James 1968, Galaktionov 1993). This study indicates that in the Barents Sea coast, the digeneans without free-living larval stages face increased competition with the more complex species in the milder western regions ( $D$ and $E$ ). Nevertheless the predominance of 'pygmaeus' microphallids in periwinkles in all regions indicates that the life cycles without free-living larval stages are still better adapted for completion under the environmental conditions of northern latitudes.

The influence of exposure on the distribution of digenean parthenites and larvae in intertidal molluscs has been discussed in earlier literature (James 1968 , Lauckner 1980, Hughes \& Answer 1982, Davey 1983, Galaktionov 1993). James (1968) concluded that species with free-swimming larvae (cercariae and/or miracidia) were restricted to the sheltered side of their the exposure range (lower level of littoral, sheltered coasts), whereas those with 1 intermediate host and no free-living larval stages in their life cycles were to be found in the upper and more exposed parts of their molluscan host's range. In this study we statistically controlled for exposure when testing for interregional differences, and in Littorina saxatilis we found a significant effect of exposure on the frequency of occurrence and prevalence of digenean species. This is not surprising, especially for the digeneans with complex life cycles, since various stages (eggs, free-swimming miracidia) may be washed out to sea from exposed sites. The relatively lower influence of exposure on the prevalence of digenean species in L. obtusata may be explained by the fact that this species inhabits more sheltered littoral microhabitats (seaweed fronds in the lower and middle levels) than L. saxatilis (Golikov 1995).

The frequency of occurrence and prevalence of digenean species in intertidal molluscs are also influenced by the availability of suitable final hosts, host density, biological characteristics and behaviour (e.g. Berry 1962, James 1968, Werding 1969, Pohley 1976, Threlfall \& Goudie 1977, Lauckner 1980, 1984b, 1987. Curtis \& Hurd 1983, Matthews et al. 1985, Galaktionov \& Dobrovolskij 1986, Newell 1986, Galaktionov \& Bustnes 1995, Galaktionov 1996). Even though the life cycle of microphallids of the 'pygmaeus' group is probably relatively independent of the physical conditions, the infestation of Microphallus piriformes, a gull digenean, in Littorina saxatilis in region A was very low. This is possibly because the gulls feed mainly on fish and forage little in the littoral zones at Novaya Zemlya and Vaygatch Island (Karpovich \& Kohanov 1967). The frequency of occurrence and prevalence of $M$. piriformes were higher further west and became more frequent than $M$. pygmaeus, which is a common eider Somateria mollissima digenean (Table 1), in the westernmost region $(E)$. A probable reason for this is that gulls tend to be more aggregated in the intertidal zones in the western, Norwegian regions, because of the human settlements and various fishery activities (Barrett \& Vader 1984, Strann 1985, Bergman 1986, Galaktionov \& Bustnes 1995, Bustnes \& Galaktionov 1999) that are absent on the Russian coast. The increase in the frequency and prevalence of $M$. piriformes in the White Sea (region B) is probably also caused by the high concentrations of gulls in the sampling area in the Kandalaksha Bay (Bianki et al. 1995).

The same interregional changes in the frequency and prevalence of Microphallus piriformes and $M$. pygmaeus were found in Littorina obtusata. The lower indices for $M$. piriformes in $L$. obtusata than in $L$. saxatilis were probably caused by the fact that $L$. obtusata inhabits a lower part of the intertidal zone (Golikov 1995), and that common eiders usually feed by diving or dabbling in the lower intertidal and upper subtidal (Catin et al, 1974, Bustnes \& Erikstad 1988) where $L$. obtusata is common, while the non-diving gulls usually concentrate in the upper and middle levels of the shore (Cramp \& Simmons 1977, Strann 1985) where L. saxatilis is more common (Golikov 1995).

Different factors could play a part in the completion of parasite life cycles in the different regions. Environmental conditions (temperature, ice) may be the dominant factors influencing digenean distribution in region A. For example, if we compare Lamchina Bay (Vaygatch Island, region A) and Yarnshnaya Bay (eastern Murman, region $\mathrm{C}$ ). They both have a relatively high concentration of common eider broods and are well protected from wave action (same exposure) ( $\mathrm{K}$. 
Galaktionov pers. obs.). However, the mean prevalence of Microphallus pygmaeus in Littorina saxatilis in the first bay was $10.1 \%$, while in the second it was $42.7 \%$.

The importance of the availability of suitable intermediate hosts is perhaps demonstrated by Microphallus similis and Cryptocotyle lingua. The prevalence of these species in periwinkles is very low in region $B$ and C. For $M$. similis this is probably because the second intermediate host, the seashore crab Carcinus maenas, is absent east of the Varangerfjord (Uspenskaya 1963, K. Galaktionov pers. obs.). Metacercariae of this digenean can also develop in the subtidal crab Hyas araneus (Uspenskaya 1963, Podlipajev 1979), but this crab is rarely found in the intertidal zone and cannot therefore serve as an agent for a high prevalence of $M$. similis in the first intermediate hosts.

The situation is different for Cryptocotyle lingua, because the fishes connected with intertidal zone (second intermediate hosts) are also numerous in eastern regions. However, the low prevalence of this parasite in periwinkles in the eastern regions may be caused by the fact that the main first intermediate host, Littorina littorea, is very rare in those areas (K. Galaktionov pers. obs.). The less specific hosts $L$. saxatilis and $L$. obtusata are probably unable to support a dense population of $C$. lingua under the relatively harsh environmental conditions prevailing on the eastern seashores. This is not the case for Himasthla sp., where the main first ( $L$. saxatilis) and the second intermediate host, the blue mussel Mytilus edulis (K. Galaktionov unpubl. data), are widely distributed. For this species, influence of exposure on the prevalence of the latter species in periwinkles has been found (Galaktionov \& Bustnes 1995). For example, the situation in some sheltered bays of Eastern Murman where the situation for completion of the Himasthla sp. life cycle is favourable (low exposure, high concentration of gulls, existence of second intermediate hosts, such as mussels), relatively high prevalence may be found in periwinkles $(6.6 \%$ in the Yarnishnaya Bay). In comparison, on the less protected seashore in the same area, Himasthla sp. was practically absent in periwinkles.

Acknowledgements. This work was financed by the Norwegian Directorate for Nature Management, Nordic Council and Russian Fund for Basic Research (grant N 98-04-49706). We wish to thank Dr Nigel Yoccoz, Dr Sam Irwin and 2 anonymous referees for comments to the manuscript. We also thank Rob Barrett for improving the English in the paper.

\section{LITERATURE CITED}

Belopolskaya MM (1952) Parasite fauna of marine waterfowl. Sci Rep Leningrad State Univ 141 (Ser Biol 28):127-180 (in Russian)
Barrett RT, Vader W (1984) The status and conservation of breeding seabirds in Norway. ICBP Techn Publ 2: 323-333

Bergman G (1986) Feeding habits, accommodation to man, breeding success and aspects of coloniality in the common gull Larus canus. Ornis Fenn 63:65-78

Berry AJ (1962) The occurrence of digenean larvae in the population of Littorina saxatilis (Olivi). Parasitology 52: $237-240$

Bianki VV, Boyko NS, Shutova EV (1995) Birds and their importance in ecosystems of the White Sea. In: Skarlato $O A$ (ed) The White Sea, biological resources and problems of their rational exploitation. Zoological Institute Pbls, St Petersburg, p 152-180 (in Russian)

Bustnes JO, Erikstad KE (1988) The diets of sympatric wintering populations of common eider Somateria mollissima and king eider $S$. spectabilis in Northern Norway. Ornis Fenn 65:163-168

Bustnes JO, Galaktionov KV (1999) Anthopogenic influences on the infestation of intertidal gastropods by seabird digenean larvae on the southern Barents Sea coast. Mar Biol 133:449-453

Cantin M, Bedard J, Milne $H$ (1974) The food and feeding of common eiders in the St. Lawrence estuary in summer. Can J Zool 52:319-334

Chubrick GK (1966) Fauna and ecology of digenean larvae from molluscs of the Barents Sea and White Sea. In: Poljanski YI (ed) Life cycles of parasitic worms from northern seas. Nauka Press, Leningrad, p 78-159 (in Russian)

Combescot-Lang C (1976) Etudes des digeneanses parasites de Littorina saxatilis (Olivi) et de leurs effet sur cet hôte. Ann Parasitol Hum Comp 51(1):27-36

Cramp S, Simmons KEL (1977) Handbook of the birds of Europe and Middle East and North Africa. The birds of the West Palearctic, Vol 1. Oxford University Press, Oxford

Curtis LA, Hurd LE (1983) Age, sex, and parasites: spatial heterogeneity in a sandflat population of Myanassa obsoleta. Ecology 64(4):819-828

Davey JT (1983) The digenean parasites of Littorina neritoides $(L$.$) in relation to microhabitat on the Plymouth$ breakwater. Can J Zool 61:1058-1061

Galaktionov KV (1992) Seasonal dynamics of the age composition of hemipopulations of daughter sporocysts of 'pygmaeus microphallids (Digenea; Microphallidae) in the intertidal molluscs Littorina saxatilis from the Barents Sea. Parazitologiya 26(6):462-463 (in Russian)

Galaktionov KV (1993) Digenean life cycles as components of ecosystems (an attempt of analysis by example of representatives of family Microphallidae). Kola Scientific Centre of the Russian Academy of Sciences Publ, Apatity (in Russian)

Galaktionov KV (1995) Long term changes of composition of the seabirds helminth fauna on the Seven Island Archipelago (eastern Murman). In: Skjoldal HR, Hopkins C, Erikstad KE, Leinås HP (eds) Ecology of fjords and coastal waters. Elsevier Science, Amsterdam, p 489-496

Galaktionov KV (1996) Life cycles and distribution of seabird helminths in Arctic and sub-Arctic regions. Bull Scand Soc Parasitol 6:31-49

Galaktionov KV, Bustnes JO (1995) Species composition and prevalence of seabird digenean larvae in periwinkles at two littoral sites in North-Norway. Sarsia 80:187-191

Galaktionov KV, Dobrovolskij AA (1986) Parasites in the ecosystems of shelf. In: Matishov GG (ed) Life and its conditions in the benthal of the Barents Sea. Kola Scientific Centre of the Russian Academy of Sciences Publ, Apatity p 160-186 (in Russian) 
Golikov AN (1995) Shell-bearing gastropods of the Arctic Colus, Moscow

Hoberg EP (1996) Faunal diversity among avian parasite assemblages: the interaction of history, ecology, and biogeography in marine systems. Bull Scand Soc Parasitol 6: $65-89$

Hoberg EP (1997) Phylogeny and historical reconstruction: Host-parasite systems as keystones in biogeography and ecology. In: Reaka-Kudla ML, Wilson DE, Wilson EO (eds) Biodiversity II: understanding and protecting our biological resources. Joseph Henry Press, National Academy of Sciences, Washington, DC, p 243--261

Hughes RN, Answer P (1982) Growth, spawning and digenean infestation of Littorina littorea (L) from a exposed shore in North Wales. J Moll Stud 48(3):321-330

Irwin SWB (1983) Incidence of digenean parasites in two populations of Littorina saxatilis (Olivi) from the north shore of Belfast Lough. Ir Nat J 21:26-29

James BL (1968) The occurrence of larval Digenea in ten species of intertidal prosobranch molluscs in Cardigan Bay. J Nat Hist 2:329-343

James BL (1969) The digena of the intertidal prosobranch, Littorina saxatilis (Olivi). Z Zool Syst Evolutionsforsch 7 : $273-316$

Karpovich VN, Kohanov VD (1967) The bird fauna of the Vaigach Island and the north-eastern part of the Yugorski Peninsula. Trans Kandalaksha State Reserve 5:268-335 (in Russian)

Kristoffersen R (1991) Occurrence of the digenean Cryptocotyle lingua in farmed Arctic charr Salvelinus alpinus and periwinkles Littorina littorea sampled close to charr farms in northern Norway. Dis Aquat Org 12:59-65

Lauckner G (1980) Diseases of Mollusca: Gastropoda. In: Kinne $O$ (ed) Diseases of marine animals, Vol I. Biologische Anstalt Helgoland, Hamburg, p 311-424

Lauckner G (1984a) Brackish-water submergence of the common periwinkle, Littorina littorea, and its digenean parasites in the Baltic Sea and in the Kattegat. Helgol Meerunters $37: 177-184$

Lauckner $G$ (1984b) Impact of digenean parasitism on the fauna of a North Sea tidal flat. Helgol Meerunters 37: $185-199$

Lauckner G (1987) Ecological effects of larval digenean intestation on littoral marine invertebrate populations. Int $\mathrm{J}$ Parasitol 17(2):391-398

Loeng $H$ (1991) Features of the physical oceanographic conditions of the Barents Sea. In: Sakshaug E, Hopkins CCE Oritsland NA (eds) Proc Pro Mare Symp on Polar Marine Ecology. Trondheim 12-16 May 1990. Polar Res 10(1):5-18

Loeng H, Blindheim J, Åndalsvik B, Ottersen G (1992) Climatic variability in the Norwegian and Barents Seas. ICES Mar Sci Symp 195:52-61

Editorial responsibility: Wolfgang Körting

Hannover, Germany
Loeng $H$, Vinje $T$ (1979) On the sea ice conditions in the Greenland and Barents Sea. In: Anon (ed) POAC 79. Proc 5th International Conf Port and Ocean engineering under Arctic conditions. The Norwegian Institute of Technology, Trondheim, p 163-174

Lonne OJ, Sætre R, Thikhonov S, Gabrielsen GW, Loeng $H_{\text {, }}$ Dahle S, Sjevljagin K (1997) Status report on the marine environment of the Barents region. Report from the joint Norwegian-Russian commission on environmental cooperation. The working group on the marine environment of the Barents Sea. Norwegian Ministry of Environment, Oslo

Matthews PM, Montgomery WI, Hanna REB (1985) Infestation of littorinids by larval digenea around a small fishing port. Parasitology 90:277-287

McCullagh P, Nelder JA (1989) Generalized linear models, 2nd edn. Chapman and Hall, London

Newell CR (1986) The marine fauna and flora of the Isles of Scilly: some marine digeneans from invertebrate hosts. J Nat Hist 20(1):71-77

Podlipajev SA (1979) Parthenites and larva of digeneans in intertidal molluscs of the Eastern Murman. Ecol Exp Parasitol 2:47-101 (in Russian)

Pohley WJ (1976) Relationships among three species of Littorina and their larval Digenea. Mar Biol 37:179-186

SAS (1990) SAS/STAT user's guide, release 6.04. SAS Institute, Cary, NC

SAS (1993) SAS technical report P-243 SAS/STAT software: the GENMOD procedure, release 6.09. SAS Institute Inc, Cary, $\mathrm{NC}$

Strann KB (1985) A comparative study of habitat use and foraging techniques in herring gull Larus a. argentatus, great black-backed gull $L$. marinus, lesser black-backed gull $L$. f. fuscus and common gull $L$. c. canus in northern Norway. Cand real thesis, University of Tromsø (in Norwegian)

Threlfall W, Goudie RI (1977) Larval digeneans in the rough periwinkle, Littorina saxatilis (Olivi), from Newfoundland. Proc HeIminthol Soc Wash 44(2):229-232

Uspenskaja AV (1963) Parasite fauna of benthic crustaceans of the Barents Sea. USSR Academy of Sciences Publ, Leningrad (in Russian)

Vinje T, Kvambekk AS (1991) Barents Sea drift ice characteristics. In: Sakshaug E, Hopkins CCE, Øritsland NA (eds) Proc Pro Mare Symp on Polar Marine Ecology. Trondheim 12-16 May 1990. Polar Res 10(1):59-68

Werding B (1969) Morphologie, Entwicklung und Ökologie digener Trematoden-Larven der Strandschnecke Littorina littorea. Mar Biol 3:306-333

Andalsvik B, Loeng H (1991) A study of the climatic system in the Barents Sea. In: Sakshaug E, Hopkins CCE, Øritsland NA (eds) Proc Pro Mare Symp on Polar Marine Ecology. Trondheim 12-16 May 1990. Polar Res 10(1):45-49

Submitted: July 27, 1998; Accepted: May 11, 1999

Proofs received from author(s): August 5, 1999 